\title{
PENGARUH KECERDASAN EMOSIONAL DAN MOTIVASI BELAJAR TERHADAP KEMAMPUAN BERPIKIR KRITIS MATEMATIKA
}

\author{
Putri Sulistianingsih \\ Rabbanii Islamic School, Jln. Cimandiri 8B, RT.06 RW.02, \\ Jatireja, Graha Asri, Cikarang Timur, Kab. Bakasi, Jawa Barat. \\ e-mail: putrisulistia1512@gmail.com
}

\begin{abstract}
Abstrak. Pengaruh Kecerdasan Emosional dan Motivasi Belajar terhadap Kemampuan Berpikir Kritis Matematika. Penelitian survai dengan analisis regresi ganda ini bertujuan untuk: (1) Mengetahui pengaruh kecerdasan emosional dan motivasi belajar secara bersamasama terhadap kemampuan berpikir kritis matematika; (2) Mengetahui pengaruh kecerdasan emosional terhadap kemampuan berpikir kritis matematika; dan (3) Mengetahui pengaruh motivasi belajar terhadap kemampuan berpikir kritis matematika. Penelitian dilaksanakan di SMA Negeri 83 Jakarta pada tahun pelajaran 2015/2016 dengan teknik pengambilan sampel adalah simple random sampling, dimana banyaknya sampel adalah 154 responden yang diambil dari populasi terjangkau sebanyak 250 responden. Instrumen yang digunakan berupa angket untuk variabel kecerdasan emosional dan motivasi belajar serta soal bentuk essay untuk variabel kemampuan berpikir kritis matematika, dimana seluruh butir angket telah divalidasi secara empirik. Pengujian hipotesis dilakukan setelah data memenuhi uji asumsi klasik berupa uji normalitas, uji linearitas, dan uji multikolinearitas. Uji regresi ganda dengan uji $\boldsymbol{F}$ dan pengujian hipotesis parsial dengan uji $\boldsymbol{t}$. Hasil penelitian menunjukkan bahwa: (1) Terdapat pengaruh yang signifikan kecerdasan emosional dan motivasi belajar secara bersama-sama terhadap kemampuan berpikir kritis matematika; (2) Terdapat pengaruh yang signifikan kecerdasan emosional terhadap kemampuan berpikir kritis matematika; (3) Terdapat pengaruh yang signifikan motivasi belajar terhadap kemampuan berpikir kritis matematika.
\end{abstract}

\section{Kata Kunci:Kecerdasan Emosional, Motivasi Belajar, Kemampuan Berpikir Kritis Matematika.}

\begin{abstract}
The Impact of Emotional Question and Study Motivation on Mathematical Critical Thinking Ability. This survey research with regression analysis is aimed at 1) acknowledging the impacts of both emotional question and study motivation on mathematical critical thinking ability all together 2) acknowledging the impacts of emotional question on mathematical critical thinking ability 3) acknowledging the impacts of study motivation on mathematical critical thinking ability. The research was conducted at SMA Negeri 83 Jakarta in 2015/2016 by using simple random sampling with 154 respondents taken from the number of affordable population reach as many as 250 respondents. The instrument used is questionnaire on variables of emotional question and study motivation, and essay test for mathematical critical thinking ability which all instruments points have been empirically validated. Hypothesis is conducted after the data fulfill in series of classic assumption test, i.e. normality test, linearity test and multicollinearity test. The research result show that 1) there are significant impacts of both emotional question and study motivation all together on mathematical critical thinking ability; 2) there are significant impacts of emotional question on mathematical critical thinking ability; 3) there are significant impacts of study motivation on mathematical critical thinking ability.
\end{abstract}

Keywords: Emotional Question, Study Motivation, Mathematical Critical Thinking Ability. 


\section{PENDAHULUAN}

Sistem pendidikan di Indonesia diatur dalam Undang-Undang Nomor 20 Tahun 2003 tentang Sistem Pendidikan Nasional. Tujuan dari pendidikan nasional dapat tercapai apabila faktor-faktor yang memengaruhinya berkualitas baik. Salah satu diantara faktor yang dimaksud adalah kualitas sumber daya manusia dalam kegiatan belajar mengajar. Peningkatan kualitas pendidikan sumber daya manusia sangat ditentukan oleh proses dan pengelolaan pendidikan yang dilakukan oleh manusia itu sendiri. Dengan proses pendidikan yang terarah dan sistematis, diharapkan akan hadir sumber daya manusia dengan kualitas yang baik dan menjadi manusia unggul. Dengan demikian, tujuan pendidikan nasional dapat dibilang terwujud dengan sukses.

Pendidikan merupakan suatu usaha atau kegiatan yang dilakukan oleh manusia secara sadar, teratur dan berencana dengan tujuan untuk menumbuhkembangkan potensi sumber daya manusia. Dalam rangka mewujudkan tujuan dari pendidikan nasional hendaknya dapat direalisasikan dengan kegiatan belajar mengajar di sekolah. Sekolah adalah lembaga formal sebagai sarana dalam rangka pencapaian tujuan pendidikan nasional. Di sekolah, peserta didik mengikuti kegiatan belajar yang diselenggarakan oleh pihak sekolah. Kegiatan belajar mengajar tersebut harus berjalan secara efektif agar sekolah dapat menghasilkan lulusan yang kompeten dan sesuai dengan tujuan pendidikan nasional. Namun pada kenyataannya, kegiatan belajar mengajar tersebut belumlah efektif secara menyeluruh. Keefektifan dari kegiatan belajar salah satunya dapat ditunjang dari beberapa faktor, diantaranya faktor internal dan faktor eksternal.
Salah satu penunjang pembelajaran dari faktor internal adalah kemampuan berpikir. Dari kegiatan belajar tersebut, peserta didik dituntut untuk dapat memahami pelajaran yang ada. Pemahaman materi dalam setiap pelajaran sangatlah ditentukan oleh kemampuan berpikir yang dimiliki oleh setiap peserta didik, diantaranya adalah kemampuan berpikir kritis. Kemampuan berpikir kritis ini sangat berguna sekali dalam proses belajar peserta didik pada tiap pelajarannya, temasuk dalam pelajaran matematika. Matematika adalah pelajaran yang dipelajari mulai dari jenjang taman kanak-kanak hingga ke jenjang pendidikan tinggi. Matematika dekat penerapannya dalam kehidupan sehari-hari. Matematika sangat erat konsepnya dengan berpikir kritis. Umumnya matematika identik dengan angka dan rumus, sehingga diperlukan kemampuan berpikir kritis untuk menyelesaikan persoalan matematika. Banyak orang beranggapan bahwa matematika merupakan mata pelajaran yang sulit sehingga banyak peserta didik merasa tidak percaya diri dan mudah putus asa dalam menyelesaikan soal. Ketika salah dalam hitungan, mereka lebih memilih menyerah dan tidak melanjutkan berhitung karena beranggapan mereka tidak bisa menyelesaikan persoalan matematika tersebut. Hal seperti itu disebabkan karena mereka memiliki kemampuan berpikir kritis yang cenderung rendah.

Banyak faktor yang memengaruhi kemampuan berpikir kritis seseorang, salah satu diantaranya adalah tentang kondisi emosi dalam diri individu. Kondisi emosi disini dimaksudkan sebagai keadaan emosional yang ditandai dengan berbagai macam perasaan yang hadir dan bergejolak saat menghadapi atau mengalami suatu peristiwa tertentu. 
Seseorang diharapkan mampu untuk mengendalikan emosi dalam dirinya dengan pengelolaan emosi yang baik serta positif. Dalam mengelola emosi ini tentu saja seseorang dituntut untuk dapat memiliki kecerdasan emosional yang baik. Kecerdasan emosional ini dapat memungkinkan memengaruhi kemampuan berpikir kritis seseorang. Semakin baik kecerdasan emosional yang dimiliki oleh seseorang, besar kemungkinan akan semakin baik pula kemampuan seseorang dalam berpikir kritis.

Pentingnya kecerdasan emosional, dirasakan saat seseorang berinteraksi dengan individu ataupun kelompok lain. Kecerdasan emosional merupakan kecakapan seseorang dalam mengelola emosinya. Pengelolaan emosi tersebut akan dapat memengaruhi berbagai kegiatan sehari-hari, termasuk juga dalam kegiatan belajar. Teori mengenai kecerdasan emosional tersebut dibuktikan pula dalam sebuah penelitian oleh Meida Adriyati dan Fatwa Patimah Nursa'adah (2015), di mana hasil penelitian tersebut menunjukkan fakta bahwa adanya pengaruh yang signifikan antara kecerdasan emosional terhadap berpikir kritis matematika peserta didik.

Faktor lain yang memungkinkan dapat memengaruhi kemampuan berpikir kritis adalah motivasi. Motivasi yang tinggi terlihat dari kapasitas dalam belajar, mengambil resiko, menjawab pertanyaan serta kesediaan untuk bertanggungjawab. Semakin kuat motivasi yang dimiliki oleh seseorang, berarti orang tersebut mempunyai kemampuan berpikir kritis yang baik. Seandainya tidak memiliki kemampuan yang baik dalam berpikir kritis, senantiasa mengoptimalkan dirinya untuk memiliki kemampuan berpikir kritis sampai maksimal. Hal tersebut dapat terjadi karena ia memiliki motivasi yang kuat dari dalam dirinya.
Peserta didik dalam pembelajaran matematika senantiasa menghadapi kesulitan pada saat menyelesaikan tugas yang diberikan guru, jika peserta didik memiliki kecerdasan emosional dan motivasi belajar yang baik, maka peserta didik akan tetap berusaha untuk mencari cara bagaimana menyelesaikan tugas tersebut. Beragam alternatif cara yang dapat dilakukan adalah dengan meminjam buku dari perpustakaan ataupun ia mencari sumber informasi dari internet yang berhubungan dengan materi pelajaran yang sedang dihadapinya. Dengan usaha yang sedemikian kuat tentunya didasari oleh pengelolaan emosi yang baik dan motivasi dalam diri peserta didik. Dari kecerdasan emosional dan motivasi belajar yang kuat tersebut, akan semakin baiklah kemampuan berpikir seseorang, termasuk kemampuan berpikir kritisnya. Setelah ia merasa bahwa tugas matematika tersebut adalah tugas yang sulit maka ia akan menyerah begitu saja dan tentu saja itu dikarenakan tingkat kecerdasan emosional dan motivasi belajarnya cenderung rendah sehingga kemampuan berpikir kritis yang dimilikinya belum maksimal.

\section{METODE}

Penelitian tentang pengaruh kecerdasan emosional dan motivasi belajar terhadap kemampuan berpikir kritis matematika ini dilaksanakan pada peserta didik kelas X di SMA Negeri 83 Jakarta. Sekolah ini secara tepat beralamat di Jln. Tipar Cakung Sukapura, Kecamatan Cilincing, Jakarta Utara, Kode Pos 14140, Telp. (021) 4403010, Fax. 4416822. Penelitian yang dilaksanakan pada bulan Maret s.d. Mei di tahun 2016 ini merupakan penelitian survai korelasional dengan analisis regresi ganda. 
Adapun desain penelitian ini digambarkan sebagai berikut:

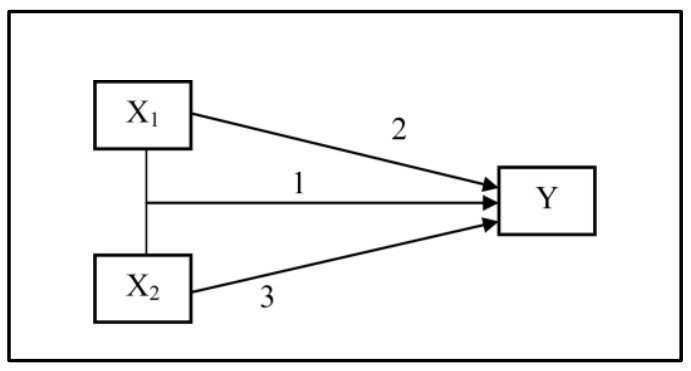

Gambar 1. Desain Penelitian

Keterangan:

$\mathrm{X}_{1}$ : Kecerdasan Emosional

$\mathrm{X}_{2}$ : Motivasi Belajar

$\mathrm{Y}$ : Kemampuan Berpikir Kritis Matematika

1 : Pengaruh Kecerdasan Emosional dan Motivasi Belajar Secara

Bersama-sama terhadap

Kemampuan Berpikir Kritis Matematika

2 : Pengaruh Kecerdasan Emosional terhadap Kemampuan Berpikir

Kritis Matematika

3 : Pengaruh Motivasi Belajar terhadap Kemampuan Berpikir Kritis Matematika

Populasi target dari penelitian ini adalah seluruh peserta didik di SMA Negeri 83 Jakarta pada tahun ajaran 2015/2016. Adapun Populasi terjangkau dalam penelitian ini adalah peserta didik kelas X yang terdiri dari 7 kelas pararel di SMA Negeri 83 Jakarta Utara tahun ajaran 2015/2016 berjumlah 250 peserta didik. Seluruh peserta didik kelas X dari tujuh kelas paralel yang ada di tempat penelitian, dipilih secara acak berupa undian untuk dijadikan sampel atau subjek pada penelitian ini. Setelah pengundian, sampel yang digunakan dalam penelitian ini adalah 154 orang peserta didik yang mana teknik menentukan jumlah sampel dengan menggunakan rumus Taro Yamane (Riduwan, 2006: 65).
Perangkat instrumen pada penelitian ini adalah nontes berupa angket. Instrumen nontes ini digunakan untuk semua variabel penelitian, yaitu kecerdasan emosional $\left(\mathrm{X}_{1}\right)$, motivasi belajar $\left(\mathrm{X}_{2}\right)$, dan kemampuan berpikir kritis matematika (Y). Instrumen penelitian divalidasi secara validitas isi dan konstruk maupun divalidasi secara empiris. Validitas isi untuk instrumen dilakukan dengan analisis isi oleh tiga orang pakar. Kemudian untuk validitas empirisnya, instrumen diujicobakan ke 30 orang peserta didik yang tidak masuk dalam sampel penelitian.

Instrumen kemampuan berpikir kritis matematika berupa soal matematika bentuknya essay dimana instrumen ini semuanya masuk dalam aspek kemampuan berpikir kritis yang disampaikan oleh Ennis (2011) yaitu: “(1) Definisi dan Klarifikasi Masalah; (2) Menilai Informasi yang Berhubungan dengan Masalah; dan (3) Memecahkan Masalah atau Membuat Simpulan”.

Instrumen kecerdasan emosional berupa angket yang terdiri dari 30 butir pernyataan dengan lima alternatif pilihan dalam menjawab, yaitu Selalu, Sering, Kadang-kadang, Pernah, dan Tidak Pernah. Satu set instrumen ini semuanya masuk dalam karakteristik kecerdasan emosional yang disampaikan oleh Zuchdi (2009) yaitu: “(1) Peserta didik mampu mengenali emosi diri sendiri; (2) Peserta didik mampu mengelola emosi; (3) Peserta didik mampu memotivasi diri; (4) Peserta didik mampu mengenali emosi orang lain; dan (5) Peserta didik mampu membina hubungan dengan orang lain". Sebanyak 48 butir pernyataan yang disiapkan, hanya 22 butir pernyataan yang digunakan sebagai sumber pengambilan data untuk kecerdasan emosional. Adapun karakteristik instrumen dan hasil ujicoba adalah: koefisien validitas dalam rentang 0,341 s.d. 0,718 meliputi tingkat validitas 
sedang, tinggi, dan sangat tinggi; koefisien reliabilitas instrumen masuk kategori sangat tinggi dengan skor 0,931 .

Instrumen motivasi belajar berupa angket yang terdiri dari 48 butir pernyataan dengan lima alternatif pilihan dalam menjawab, yaitu Selalu, Sering, Kadang-kadang, Pernah, dan Tidak Pernah. Satu set instrumen ini semuanya masuk dalam indikator motivasi belajar yang disampaikan oleh Sardiman (2001) dan Uno (2008) yaitu: "peserta didik memiliki keinginan untuk berhasil dalam pelajaran matematika, peserta didik menyadari kebutuhan dalam belajar matematika, peserta didik memiliki harapan dan cita-cita masa depan dalam pelajaran matematika, peserta didik sadar akan penghargaan dalam mengikuti pelajaran matematika, peserta didik menemukan kegiatan yang menarik dalam belajar matematika, peserta didik membutuhkan lingkungan belajar yang kondusif, peserta didik memiliki ketekunan dalam menghadapi tugas matematika, peserta didik memiliki sikap ulet dalam menghadapi kesulitan, peserta didik menunjukkan minat terhadap bermacam-macam masalah matematika, peserta didik lebih senang belajar matematika secara mandiri, peserta didik menanggapi secara baik terkait tugas-tugas rutin, dan peserta didik sadar bahwa dengan matematika ia mampu mempertahankan pendapatnya". Sebanyak 48 butir pernyataan yang disiapkan, hanya 39 butir pernyataan yang digunakan sebagai sumber pengambilan data untuk motivasi belajar. Adapun karakteristik instrumen dan hasil ujicoba adalah: koefisien validitas dalam rentang 0,341 s.d. 0,718 meliputi tingkat validitas sedang, tinggi, dan sangat tinggi; koefisien reliabilitas instrumen masuk kategori sangat tinggi dengan skor 0,931 .
Teknik analisis terhadap data hasil penelitian yang dalam hal ini berupa perolehan total skor atas angket kecerdasan emosional $\left(\mathrm{X}_{1}\right)$, motivasi belajar $\left(\mathrm{X}_{2}\right)$, dan kemampuan berpikir kritis matematika (Y) dilakukan secara deskriptif dan inferensial. Secara deskriptif, data hasil penelitian dianalisis untuk skor mean, median, dan modus. Adapun maksud analisis skor mean, median, dan modus adalah untuk mendeskripsikan perolehan ukuran pemusatan data dari peserta didik yang menjadi subjek penelitian. Secara inferensial, data hasil penelitian dianalisis menggunakan uji $\boldsymbol{F}$ dan uji $\boldsymbol{t}$, dengan terlebih dahulu diuji untuk persyaratan analisisnya yaitu uji normalitas, uji linearitas, dan uji multikolinearitas. Perhitungan data hasil penelitian secara keseluruhan dilakukan dengan menggunakan bantuan software Ms. Excel.

\section{HASIL DAN PEMBAHASAN}

\section{Hasil Penelitian}

Jumlah sampel dalam penelitian sebagaimana telah dikemukakan yaitu sebanyak 154 peserta didik dengan jumlah responden laki-laki sebanyak 32 peserta didik dan perempuan 24 peserta didik. Karakteristik responden dalam penelitian ini heterogen berdasarkan aspek kognitifnya, dimana peserta didik yang menjadi responden secara tingkatan kognitifnya ada kelompok atas, kelompok sedang, dan kelompok rendah. Adapun pengelompokkan tinggi, sedang, dan rendah ini berdasarkan pada hasil belajar matematika yang diraih di setiap akhir pembelajaran, berupa tes ulangan harian atau tes ujian tengah semester, dan tes ujian akhir semester. Kemudian, karakteristik responden dalam penelitian ini juga ditinjau berdasarkan aspek 
psikologis. Responden berada di fase remaja, fase dimana seorang remaja mengalami perkembangan emosional. Fase ini terjadi perkembangan emosi yang tinggi, perkembangan kemampuan untuk memahami orang lain, dan menjalin persahabatan. Remaja juga sudah mampu berperilaku yang tidak hanya mengejar kepuasan fisik saja, tetapi meningkat pada tatanan psikologis (rasa diterima, dihargai, dan penilaian positif dari orang lain).

Secara deskriptif, pada penelitian ini yang menjadi variabel terikat (Y) adalah berpikir kritis matematika. Data berpikir kritis matematika diperoleh dari perangkat instrumen nontes yaitu angket dengan 41 butir pernyataan. Kemudian, yang menjadi variabel bebas $\left(\mathrm{X}_{1}\right)$ adalah kecerdasan emosional. Data kecerdasan emosional diperoleh dari penyebaran angket sebanyak 22 butir pernyataan. Serta yang menjadi variabel bebas $\left(\mathrm{X}_{2}\right)$ adalah motivasi belajar. Data motivasi belajar diperoleh dari penyebaran angket sebanyak 37 butir pernyataan. Adapun ringkasan deskripsi hasil penelitian ditampilkan pada tabel 1 .

Tabel 1. Ringkasan Hasil Perhitungan Statistik Deskriptif

\begin{tabular}{cccc}
\hline Data Statistik & Berpikir Kritis Matematika & Kecerdasan Emosional & Motivasi Belajar \\
\hline Nilai Terendah & 66 & 47 & 67 \\
Nilai Tertinggi & 190 & 95 & 184 \\
Mean & 133,94 & 74,90 & 124,40 \\
Median & 131,00 & 76,00 & 122,00 \\
Modus & 120 & 80 & 115 \\
Varians & 498,85 & 98,53 & 428,09 \\
Standar Deviasi & 22,34 & 9,93 & 20,69 \\
Simpangan Baku & 1,8 & 0,8 & 1,6 \\
\hline
\end{tabular}

Sumber: Data primer yang diolah

Secara inferensial, data hasil penelitian diuji untuk asumsi klasiknya atau uji persyaratan analisisnya, yaitu uji normalitas, uji linearitas, dan uji multikolinearitas. Uji normalitas data dilakukan untuk mengetahui apakah distribusi data untuk setiap kelompok sampel yang diteliti apakah normal atau tidak. Perhitungan uji normalitas pada penelitian ini dilakukan dengan uji $C h i$ Square yang perhitungan secara teknisnya menggunakan bantuan software Ms. Excel. Adapun kriteria pengujian normalitas adalah jika $\chi_{\text {hitung }}^{2}<\chi_{\text {tabel }}^{2}$, maka distribusi data dinyatakan normal dan sebaliknya jika $\chi_{\text {hitung }}^{2}>\chi_{\text {tabel }}^{2}$, maka distribusi data dinyatakan tidak normal. Berdasarkan tabel 2 di bawah ini, terlihat bahwa seluruh kelompok sampel yang diteliti memiliki $\chi_{\text {hitung }}^{2}<\chi_{\text {tabel }}^{2}, \quad$ sehingga dapat disimpulkan bahwa seluruh kelompok sampel dalam penelitian ini datanya berdistribusi normal. Atau dengan kata lain, sampel yang digunakan dalam penelitian ini berasal dari populasi yang berdistribusi normal.

Tabel 2. Ringkasan Hasil Perhitungan Uji Normalitas Data

\begin{tabular}{|c|c|c|c|c|}
\hline Kelompok Data & $\begin{array}{l}\text { Jumlah } \\
\text { Sampel }\end{array}$ & $\chi_{\text {hitung }}^{2}$ & $\chi_{\text {tabel }}^{2}$ & Simpulan \\
\hline Berpikir Kritis Matematika & 154 & 9,00 & 14,06 & Berdistribusi Norma \\
\hline Kecerdasan Emosional & 154 & 7,50 & 15,50 & Berdistribusi Normal \\
\hline Motivasi Belajar & 154 & 9,18 & 14,06 & Berdistribusi Normal \\
\hline
\end{tabular}

Sumber: Data primer yang diolah 
Uji asumsi klasik yang berikutnya adalah uji linearitas. Pengujian linearitas dimaksudkan untuk mengetahui apakah dua variabel berpola linear antara satu sama lainnya. Dengan kata lain, uji linearitas dilakukan dalam rangka menguji model persamaan suatu variabel terikat atas suatu variabel bebas. Kriteria pengujiannya adalah jika $\mathrm{F}_{\text {hitung }}<\mathrm{F}_{\text {tabel }}$, maka kedua variabel berpola linear dan sebaliknya jika $F_{\text {hitung }}$ $>\mathrm{F}_{\text {tabel}}$, maka kedua variabel berpola tidak linear. Oleh karena pada penelitian ini terdapat satu variabel terikat (Y) dan dua variabel bebas $\left(\mathrm{X}_{1}\right.$ dan $\left.\mathrm{X}_{2}\right)$, maka ada dua uji linearitas, yaitu uji linearitas $\mathrm{X}_{1}$ terhadap $\mathrm{Y}$ dan uji linearitas $\mathrm{X}_{2}$ terhadap Y.

Ringkasan hasil perhitungan uji linearitas $\mathrm{X}_{1}$ terhadap $\mathrm{Y}$ diperoleh $\mathrm{F}_{\text {hitung }}$ $=-13,19$ dan $F_{\text {tabel }}=1,51$. Simpulan: karena $F_{\text {hitung }}<\mathrm{F}_{\text {tabel }}$, maka kedua variabel berpola linear. Atau dengan kata lain, data hasil penelitian untuk variabel kecerdasan emosional dan berpikir kritis matematika berpola linear. Kemudian ringkasan hasil perhitungan uji linearitas $\mathrm{X}_{2}$ terhadap $\mathrm{Y}$ diperoleh $\mathrm{F}_{\text {hitung }}=0,28$ dan $\mathrm{F}_{\text {tabel }}=1,45$. Simpulan: karena $F_{\text {hitung }}<F_{\text {tabel }}$, maka kedua variabel berpola linear. Atau dengan kata lain, data hasil penelitian untuk variabel motivasi belajar dan berpikir kritis matematika berpola linear.

Uji asumsi klasik yang terakhir yaitu uji multikolinearitas. Pengujian multikolinearitas dimaksudkan untuk mengetahui hubungan antar variabel bebas, yaitu menguji ada atau tidaknya masalah multikolinearitas antara $\mathrm{X}_{1}$ dan $\mathrm{X}_{2}$. Kriteria pengujian multikolinearitas yaitu jika nilai Variance Inflation Factor $<10$, maka kedua variabel bebas tidak terdapat masalah multikolinearitas. Ringkasan hasil perhitungan uji multikolinearitas diperoleh nilai Variance Inflation Factor $=1,78$. Dengan demikian dapat disimpulkan dalam model regresi tidak terdapat masalah multikolinearitas antara kecerdasan emosional $\left(\mathrm{X}_{1}\right)$ dan motivasi belajar $\left(\mathrm{X}_{2}\right)$.

Setelah data hasil penelitian memenuhi seluruh rangkaian uji asumsi klasik, selanjutnya data hasil penelitian diuji hipotesisnya. Adapun uji hipotesis penelitian dilakukan dengan dua cara, yang pertama yaitu dengan uji $\boldsymbol{F}$ untuk membuktikan pengaruh kecerdasan emosional dan motivasi belajar secara bersama-sama terhadap kemampuan berpikir kritis matematika. Kemudian cara kedua yaitu dengan uji $\boldsymbol{t}$ untuk membuktikan pengaruh kecerdasan emosional terhadap kemampuan berpikir kritis matematika dan membuktikan pengaruh motivasi belajar terhadap kemampuan berpikir kritis matematika. Berikut ini ringkasan hasil pengujian hipotesis penelitian.

1. Pengaruh Kecerdasan Emosional dan Motivasi Belajar Secara Bersamasama terhadap Kemampuan Berpikir Kritis Matematika

Hipotesis tersebut diuji menggunakan uji $\boldsymbol{F}$ dengan kriteria pengujian: terima $\mathrm{H}_{0}$ jika $\mathrm{F}_{\text {hitung }}<$ $\mathrm{F}_{\text {tabel }}$, dan tolak $\mathrm{H}_{0}$ jika $\mathrm{F}_{\text {hitung }}>\mathrm{F}_{\text {tabel }}$. Untuk nilai $\mathrm{F}_{\text {tabel }}$ ditentukan dari tabel distribusi $F$ untuk $\alpha=0,05$ serta $d k_{\text {pembilang }}=2$ dan $d k_{\text {penyebut }}=$ 151 , besarnya nilai $F_{\text {tabel }}=3,172$. Setelah dilakukan perhitungan pada data hasil penelitian, diperoleh nilai $\mathrm{F}_{\text {hitung }}=175,14$.

Dengan demikian ternyata $\mathrm{F}_{\text {hitung }}>\mathrm{F}_{\text {tabel }}$ atau $175,14>3,172$ maka tolak $\mathrm{H}_{0}$ dan terima $\mathrm{H}_{1}$, hal ini dapat diartikan bahwa terdapat pengaruh yang signifikan kecerdasan emosional $\left(\mathrm{X}_{1}\right)$ dan motivasi belajar $\left(\mathrm{X}_{2}\right)$ secara bersama-sama terhadap kemampuan berpikir kritis matematika (Y). Persamaan regresi ganda yang tebangun adalah $\widehat{\boldsymbol{Y}}=5,69+0,52 \boldsymbol{X}_{1}+0,71 \boldsymbol{X}_{2} \quad$ dan 
besarnya kontribusi pengaruh yang signifikan kecerdasan emosional dan motivasi belajar secara bersamasama terhadap kemampuan berpikir kritis matematika adalah 69,9\%.

2. Pengaruh Kecerdasan Emosional terhadap Kemampuan Berpikir Kritis Matematika

Hipotesis tersebut diuji menggunakan uji $\boldsymbol{t}$ dengan kriteria pengujian: terima $\mathrm{H}_{0}$ jika $\boldsymbol{t}_{\text {hitung }}<$ $\boldsymbol{t}_{\text {tabel}}$, dan tolak $\mathrm{H}_{0}$ jika $\boldsymbol{t}_{\text {hitung }}>\boldsymbol{t}_{\text {tabel }}$. Untuk nilai $\boldsymbol{t}_{\text {tabel }}$ ditentukan dari tabel distribusi $\boldsymbol{t}$ untuk $\alpha=0,05$ pada $d k$ $=151$, besarnya nilai $\boldsymbol{t}_{\text {tabel }}=1,98$. Setelah dilakukan perhitungan pada data hasil penelitian, diperoleh nilai $\boldsymbol{t}_{\text {hitung }}=3,88$.

Dengan demikian, ternyata $\boldsymbol{t}_{\text {hitung }}>\boldsymbol{t}_{\text {tabel }}$ yaitu 3,88 $>1,98$, maka $\mathrm{H}_{0}$ ditolak dan terima $\mathrm{H}_{1}$, hal ini dapat diartikan terdapat pengaruh yang signifikan kecerdasan emosional $\left(\mathrm{X}_{1}\right)$ terhadap prestasi belajar matematika (Y). Adapun besarnya kontribusi pengaruh yang signifikan kecerdasan emosional terhadap kemampuan berpikir kritis matematika adalah $15,6 \%$.

3. Pengaruh Motivasi Belajar terhadap Kemampuan Berpikir Kritis Matematika

Hipotesis tersebut diuji menggunakan uji $\boldsymbol{t}$ dengan kriteria pengujian: terima $\mathrm{H}_{0}$ jika $\boldsymbol{t}_{\text {hitung }}<$ $\boldsymbol{t}_{\text {tabel}}$, dan tolak $\mathrm{H}_{0}$ jika $\boldsymbol{t}_{\text {hitung }}>\boldsymbol{t}_{\text {tabel }}$. Untuk nilai $\boldsymbol{t}_{\text {tabel }}$ ditentukan dari tabel distribusi $\boldsymbol{t}$ untuk $\alpha=0,05$ pada $d k$ $=151$, besarnya nilai $\boldsymbol{t}_{\text {tabel }}=1,98$. Setelah dilakukan perhitungan pada data hasil penelitian, diperoleh nilai $\boldsymbol{t}_{\text {hitung }}=11,12$.

Dengan demikian, ternyata $\boldsymbol{t}_{\text {hitung }}>\boldsymbol{t}_{\text {tabel }}$ yaitu $11,12>1,98$, maka $\mathrm{H}_{0}$ ditolak dan terima $\mathrm{H}_{1}$, hal ini dapat diartikan terdapat pengaruh yang signifikan motivasi belajar $\left(\mathrm{X}_{2}\right)$ terhadap prestasi belajar matematika
(Y). Adapun besarnya kontribusi pengaruh yang signifikan motivasi belajar terhadap kemampuan berpikir kritis matematika adalah 54,3\%.

\section{Pembahasan Hasil Penelitian}

1. Pengaruh Kecerdasan Emosional dan Motivasi Belajar Secara Bersamasama terhadap Kemampuan Berpikir Kritis Matematika

Berdasarkan hasil penelitian, besarnya kontribusi pengaruh yang signifikan kecerdasan emosional dan motivasi belajar secara bersamasama terhadap kemampuan berpikir kritis matematika adalah 69,9\%. Pendidikan merupakan hal penting dan wajib dilaksanakan oleh setiap orang. Melalui pendidikan yang baik, seseorang dapat meningkatkan kualitas dirinya di segala aspek kehidupan. Salah satu cara untuk mendapatkan pendidikan yang baik melalui kegiatan pendidikan secara formal adalah dengan mengikuti kegiatan belajar mengajar di sekolah.

Sekolah sebagai lembaga formal yang dapat mencetak sumber daya manusia dengan kualitas yang baik. Di dalam sekolah, banyak sekali interaksi selama kegiatan belajar mengajar berlangsung. Interaksi tersebut akan melibatkan emosi dan juga motivasi seseorang dalam belajar sehingga dapat memengaruhi kemampuan berpikir kritis seseorang. Seseorang yang memiliki kecerdasan emosional dan motivasi belajar yang baik, umumnya tingkat kemampuan berpikir kritisnya pun akan baik pula. Kemampuan berpikir kritis ini dapat menjadi indikator keberhasilan seseorang dalam melakukan kegiatan pendidikan, sehingga kemampuan berpikir kritis harus dibangun dengan sebaik-baiknya dalam setiap pelaksanaan pembelajaran. 
2. Pengaruh Kecerdasan Emosional terhadap Kemampuan Berpikir Kritis Matematika

Mengacu pada perhitungan data hasil penelitian untuk data kemampuan berpikir kritis matematika dan kecerdasan emosional, dapat disimpulkan bahwa kecerdasan emosional berpengaruh signifikan terhadap kemampuan berpikir kritis matematika. Besarnya kontribusi pengaruh yang signifikan kecerdasan emosional terhadap kemampuan berpikir kritis matematika adalah 15,6\%. Daud (2012) menyatakan bahwa, kecerdasan emosional dan motivasi belajar berpengaruh positif dan nyata terhadap hasil belajar.

Kemampuan berpikir kritis merupakan kesanggupan seseorang untuk berpikir menggabungkan hal yang kualitatif dan kuantitatif. Kemampuan berpikir kritis ini dapat membantu seseorang dalam menangkap pelajaran yang tengah berlangsung. Seseorang akan sangat membutuhkan kemampuan berpikir kritis yang baik guna membantu ia dalam memahami materi disemua pelajaran termasuk dalam pelajaran matematika. Matematika dipelajari secara umum mulai dari tingkat TK hingga perguruan tinggi. Matematika erat kehadirannya dalam kehidupan sehari-hari. Namun, kenyataannya banyak sekali orang yang kerap kali menganggap matematika sebagai suatu hal yang sulit dikarenakan matematika selalu berkaitan dengan angka dan rumus. Hal tersebut disebabkan karena rendahnya kemampuan berpikir kritis matematika yang dimiliki.

Kemampuan berpikir kritis dapat dipengaruhi oleh beberapa faktor, salah satu diantaranya adalah kecakapan seseorang dalam mengelola emosi atau yang biasa disebut sebagai kecerdasan emosional. Jika kecerdasan emosional semakin baik, maka semakin tinggi kemampuan berpikir kritis yang dimiliki oleh orang tersebut. Hal itu telah terbukti dari hasil penelitian yang telah dihitung diatas bahwa terdapat korelasi (hubungan) antara kecerdasan emosional terhadap kemampuan berpikir kritis matematika. Artinya terdapat pengaruh antara kecerdasan emosional terhadap kemampuan berpikir kritis matematika.

3. Pengaruh Motivasi Belajar terhadap Kemampuan Berpikir Kritis Matematika

Mengacu pada perhitungan data hasil penelitian untuk data kemampuan berpikir kritis matematika dan motivasi belajar, dapat disimpulkan bahwa motivasi belajar peserta didik berpengaruh signifikan terhadap kemampuan berpikir kritis matematika. Besarnya kontribusi pengaruh yang signifikan motivasi belajar peserta didik terhadap kemampuan berpikir kritis matematika adalah 54,3\%. Rahmawati (2013) menyatakan bahwa terdapat pengaruh yang nyata antara motivasi belajar dengan kemampuan berpikir kritis.

Faktor lain yang memengaruhi kemampuan berpikir kritis adalah motivasi belajar yang dimiliki dalam diri seseorang. Semakin tinggi motivasi belajar yang dimiliki dalam diri, akan semakin tinggi pula kemampuan berpikir kritis yang dimiliki oleh orang tersebut. Hal itu telah terbukti dari hasil penelitian yang telah dihitung di atas bahwa terdapat korelasi (hubungan) antara motivasi belajar terhadap kemampuan berpikir kritis matematika. 


\section{SIMPULAN DAN SARAN}

\section{Simpulan}

Berdasarkan penelitian dan perhitungan yang dilakukan oleh peneliti, didapatkan simpulan hasil penelitian terdapat pengaruh yang signifikan kecerdasan emosional dan motivasi belajar secara bersama-sama terhadap kemampuan berpikir kritis matematika. Kemudian, terdapat pengaruh yang signifikan kecerdasan emosional terhadap kemampuan berpikir kritis matematika. Serta, terdapat pengaruh yang signifikan motivasi belajar terhadap kemampuan berpikir kritis matematika.

\section{Saran}

Beberapa saran dari peneliti berdasar pada hasil penelitian dan pembahasan hasil penelitian yang sudah dipaparkan, diantaranya bagi peserta didik perlu adanya kesadaran bahwa kecerdasan emosional dan motivasi belajar memengaruhi kemampuan berpikir kritis matematika. Dengan demikian peserta didik dapat melakukan usaha-usaha yang dapat meningkatkan kemampuan berpikir kritis matematika di dalam pribadinya masing-masing. Bagi pihak sekolah, hendaknya berupaya memberi kegiatan yang dapat meningkatkan wawasan serta pemikiran peserta didik dalam menanggapi pelajaran matematika. Hal tersebut bertujuan agar peserta didik tidak mudah putus asa dan dapat mengelola emosinya dengan baik saat kegiatan belajar matematika berlangsung, baik belajar di sekolah maupun di luar sekolah. Guru harus mampu membuat sebuah inovasi dalam melaksanakan pembelajaran matematika yang dapat menggerakkan peserta didik agar terpacu untuk mengembangkan kompetensi dalam dirinya sehingga mampu meningkatkan kecerdasan emosional serta membangkitkan motivasi belajarnya. Sehingga pada akhirnya dapat meningkat pula kemampuan berpikir kritis peserta didik dalam belajar matematika. Untuk pembaca, jika ingin melakukan penelitian lebih lanjut terkait variabel yang sama, maka disarankan untuk memilih sampel dari tingkatan yang berbeda, seperti tingkatan anak sekolah dasar, sekolah menengah pertama ataupun tingkatan mahasiswa.

\section{DAFTAR PUSTAKA}

Adriyati, M. \& Fatwa P. N. 2015. Pengaruh Kecerdasan Emosional dan Kecerdasan Intrapersonal terhadap Berpikir Kritis Matematika Peserta Didik. Prosiding Seminar Nasional Pendidikan Matematika. Jakarta: Program Studi Pendidikan Matematika Universitas Indraprasta PGRI.

Daud, F. 2012. Pengaruh Kecerdasan Emosional dan Motivasi Belajar terhadap Hasil Belajar Biologi Siswa SMA 3 Negeri Kota Palopo. Jurnal Pendidikan dan Pembelajaran UNM Makassar, Volume 19, Nomor 2.

Ennis, R. H. 2011. The Nature of Critical Thinking: An Outline of Critical Thinking Dispositions and Abilities. University of Illinois.

Goleman, D. 2006. Emotional Intelligence-Kecerdasan Emosional-Mengapa EI Lebih Penting Daripada IQ. Cetakan ke-16. Jakarta: Gramedia Pustaka Utama.

Mulyana, T. H., dkk. 2007. Laporan Hasil Akhir Penelitian, Hibah Bersaing Perguruan Tinggi XIV - Pengembangan Pembelajaran Matematika Berbasis Masalah Untuk Meningkatkan Kemampuan Berpikir Kritis \& Kreatif Peserta didik SMP. Bandung: Universitas Pendidikan Indonesia. 
Rahmawati, B. F. 2013. Meningkatkan Motivasi Belajar dan Kemampuan Berpikir Kritis Mahasiswa melalui Model Pembelajaran Berbasis Masalah. Jurnal Education Vol. 8, No. 2. Lombok: STKIP Hamzanwadi Selong.

Sari, D. N. dan Nurchasanah. 2012. Kemampuan Berpikir Kritis yang Tercermin dalam Keterampilan Membaca Peserta didik Kelas XII IPA 1 SMA Islam Almaaruf. Singosari. Tesis. Yogyakarta: Program Pasca Sarjana UNY.

Sugiyono. 2010. Metode Penelitian Kuantitatif, Kualitatif, dan Kombinasi (Mixed Metods). Bandung: Alfabeta.

Supardi. 2013. Aplikasi Statistika dalam Penelitian. Jakarta: Prima Ufuk Semesta.

Uno, H. B. 2008. Teori Motivasi \& Pengukurannya-Analisis di Bidang Pendidikan. Edisi 1 Cetakan ke-4. Jakarta: Bumi Aksara.

Zuchdi, D. 2009. Humanisasi Pendidikan. Jakarta: Bumi Aksara. 